\title{
A AULA COMO OBJETO DA PROTEÇÃO DOS DIREITOS DE AUTOR: UM GUIA PARA PROFESSORES CONTRA A DIVULGAÇÃO NÃO AUTORIZADA DE SUAS AULAS
}

CLASSES AS THE OBJECT OF COPYRIGHT PROTECTION: A GUIDE TO PROFESSORS AND TEACHERS AGAINST UNAUTHORIZED DISCLOSURE OF THEIR CLASSES

Hugo luís Pena Ferreira* | Carlos Augusto de Oliveira Diniz**

RESUMO

Ganhou relevância jurídica a pretensão de gravação de aulas para instruir denúncias contra professores por aquilo que é enigmaticamente referido como "doutrinação". O incentivo à gravação e divulgação não autorizada de aulas de professores integra as táticas do movimento "Escola Sem Partido" (ESP), que impulsiona uma agenda multinível de alterações normativas com sentido geral de limitação da liberdade docente. A apresentação do ESP como "apartidário" por seus partidários é uma tentativa de encobrir sua forte proposta de negação do pluralismo político afirmado como fundamento da República no primeiro artigo da Constituição de 1988. O ordenamento jurídico protege as aulas como propriedade autoral do professor, a que correspondem direitos morais e patrimoniais. Tal proteção jurídica significa que a circulação de vídeos e gravações de aulas, sem autorização do professor, viola direitos de autor e enseja a responsabilidade civil de quem gravou e circulou indevidamente. $O$ presente artigo pretende contribuir para visibilizar expedientes jurídicos disponíveis para professores que tenham seus direitos de autor violados. 0 objetivo principal é responder à questão: de que direitos dispõem professores cujas aulas tenham sido gravadas e divulgadas sem sua autorização, no contexto de perseguição à liberdade de expressão e ensinoaprendizagem por movimentos políticos como o ESP?

Palavras-chave: liberdade de cátedra; direitos de autor; propriedade imaterial; responsabilidade civil; "Escola Sem Partido".

\section{ABSTRACT}

The intent of recordin'g classes as a means to consubstantiate claims against teachers and professors for so-called "indoctrination" has recently gained legal relevance. Inciting the recording and unauthorized public exposure of classes is one of the tactical expedients adopted by the "Escola Sem Partido" (ESP) - School Without Parties - movement, which pursues a multilevel agenda of statutory change geared towards restricting academic freedom. ESP is presented as non-partisan by its partisans, who attempt to cover their strong denial of political pluralism embodied in the Brazilian Constitution of 1988. The Brazilian legal system protects classes as copyright property pertaining to teachers/professors, to which moral and material entitlements ensue. Such legal protection means unauthorized public disclosures of videos or recordings of classes violate author's entitlements and implicate civil liability of those responsible for unduly recording and disclosing them. This paper intends to highlight procedures available to teachers and professors whose copyright entitlements over classes have been breached. The main objective is to provide answers to the question: that rights do teachers and professors whose classes have been recorded and divulged without their authorization have, especially in a context of persecutory incentives carried out by political movements such as the ESP?

Keywords: academic freedom, copyright, immaterial property, civil liability; "Escola Sem Partido" ("School Without Parties").

\footnotetext{
* Doutor em Direito pela Universidade de Brasília (UnB).

Professor do Curso de Direito da Universidade Federal de Goiás (UFG) hlpfhugo@gmail.com
}
** Doutor em Direito pela Pontifícia Universidade Católica de São Paulo (PUC-SP). Professor do Curso de Direito da Universidade Federal de Jataí (UFJ) carlosaugustodiniz@hotmail.com


A aula como objeto da proteção dos direitos de autor: um guia para professores contra a divulgação não autorizada de suas aulas

\section{SUMÁRIO}

INTRODUÇÃO; 1 O PROJETO ESCOLA SEM PARTIDO E O INCENTIVO À FILMAGEM E DIVULGAÇÃO DE AULAS; 2 DIREITOS DE AUTOR: REPRODUÇÃO DE AULAS GRAVADAS E DIREITOS PATRIMONIAIS DO PROFESSOR; 2.1 Direito autoral, direitos de autor e direitos conexos; 2.2 Direitos autorais como direitos personalíssimos: entre coisas e não-coisas; $2.3 \mathrm{~A}$ proteção jurídica da aula como direito personalíssimo do professor; 3 RESPONSABILIDADE CIVIL POR VIOLAÇÃO DE DIREITOS DE AUTOR CORRESPONDENTES À VEICULAÇÃO NÃO AUTORIZADA DE AULAS GRAVADAS; CONSIDERAÇÕES FINAIS; REFERÊNCIAS

\section{INTRODUÇÃO}

Artigo publicado pelo jornal "Gazeta do Povo" em novembro de 2017 buscou orientar como pais deveriam proceder em casos de "doutrinação ideológica por professores". 0 subtítulo da manchete afirmou que, com ou sem lei que aprovasse o projeto "Escola Sem Partido", seria possível recorrer ao Judiciário em casos de "abuso em sala de aula". O conteúdo da matéria é uma entrevista com o advogado Rafael Panichi. A segunda pergunta feita pela jornalista ao advogado indagava sobre os tipos de prova necessários para formular uma denúncia contra professores. A resposta do advogado começa com a afirmação de que "[t]odas as provas que não ilícitas podem corroborar a denúncia", e termina arrolando "filmagens" como meios de prova admitidos. ${ }^{1}$

Poucos dias depois, a Gazeta do Povo lançou o "Monitor da Doutrinação", descrito pelo jornal como "uma ferramenta que se propunha a receber relatos de doutrinação ideológica nas salas de aula brasileiras, que seriam publicados após rigorosa apuração jornalística". Em essência, a plataforma incentivava o envio ao jornal de vídeos de professores que estivessem "doutrinando" seus alunos, aos quais a Gazeta do Povo poderia dar publicidade. O portal foi, após críticas, retirado do ar pelo próprio veículo de imprensa².

Na esteira das eleições de 2018, a então deputada estadual eleita em Santa Catarina, Ane Caroline Campagnolo, publicou em redes sociais incentivo a que estudantes filmassem e enviassem vídeos de professores. A postagem dizia: "[f]ilme ou grave todas as manifestações político-partidárias ou ideológica." (sic) À época, o juiz Eduardo Luz, da Vara de Infância e Juventude de Florianópolis, proferiu decisão pela retirada do conteúdo das publicações da deputada, por considerar não somente que o uso de celulares em sala de aula é proibido pela legislação estadual catarinense, mas também que a postagem "fere diretamente o direito dos alunos de usufruírem a liberdade de expressão da atividade intelectual, científica e de comunicação, e que deve ser exercida em sala de aula e no ambiente escolar

\footnotetext{
${ }^{1}$ GUGLIELMO, Brina. O que os pais podem fazer diante de casos de doutrinação ideológica? Gazeta do Povo, 6 nov. 2017. Disponível em: https://www.gazetadopovo.com.br/educacao/o-que-os-pais-podem-fazer-diante-decasos-de-doutrinacao-ideologica-9ket0n3op8kjeecb3sa7g1g82/ Acesso em: 26. mar. 2020.

2 GAZETA DO POVO. Gazeta do Povo tira do ar "Monitor da Doutrinação". Entenda por quê. Gazeta do Povo, 10 dez. 2017. Disponível em: https://www.gazetadopovo.com.br/educacao/gazeta-do-povo-tira-do-ar-monitor-dadoutrinacao-entenda-por-que-3lf43x0adm4bz2nc0p95/gqvo/. Acesso em: 26 mar. 2020.
} 
independentemente de censura ou licença" ${ }^{3}$. A decisão, no entanto, foi revertida por decisão monocrática em segunda instância no início de 2019, voltando a permitir que a deputada incentive as gravações em sala de aula 4 .

A sequência de eventos narrados acima sinaliza que ganhou relevância jurídica a pretensão de filmagem ou gravação de aulas para instruir denúncias contra professores por aquilo que é enigmaticamente referido como "doutrinação". O movimento "Escola Sem Partido" (ESP) impulsiona a agenda multinível de alterações legislativas - nos âmbitos municipal, estadual e federal - e de litígios judiciais que, em seu conjunto, assumem o sentido geral de limitação da liberdade docente ${ }^{5}$. Tais movimentações são elementos de uma empreitada mais ampla: um projeto de reconfiguração cultural do papel do professor, consistente em posicioná-lo, em termos práticos, como um "inimigo público", um perigo à formação de crianças e jovens, a ser fiscalizado, denunciado e coibido. Como resultado, a liberdade de expressão e de ensino aprendizagem é colocada em xeque.

O aspecto da propriedade intelectual passa ao largo do incentivo que o ESP faz à cessão não autorizada de aulas gravadas. O ordenamento jurídico protege as aulas como propriedade autoral do professor, a que correspondem direitos morais e patrimoniais. Tal proteção jurídica significa que a circulação de vídeos e gravações de aulas, sem autorização do professor, viola direitos de autor e enseja a responsabilidade civil de quem gravou e circulou indevidamente. Esse parece ser ou um ponto-cego na narrativa jurídica do ESP, ou um aspecto propositalmente negligenciado: dado que o aspecto de direitos de autor, associados ao direito à propriedade privada, comprometem a licitude dos procedimentos estimulados para denúncia a professores.

Nesse sentido, o presente artigo pretende contribuir para visibilizar expedientes jurídicos disponíveis para professores que tenham seus direitos de autor violados. Pretendese, assim, responder a seguinte questão: de que direitos dispõem professores cujas aulas, uma vez gravadas, tenham sido divulgadas sem sua autorização, no contexto de perseguição à liberdade de expressão e ensino-aprendizagem por movimentos como o ESP?

Para tanto, a primeira seção levanta aspectos caracterizadores do movimento ESP e de sua campanha pela reconfiguração cultural do papel do professor e pela limitação jurídica à liberdade docente. Em seguida, a segunda seção aborda o regime da propriedade intelectual aplicável às aulas e os direitos patrimoniais envolvidos. A terceira seção aborda a responsabilidade civil por violação de direitos de autor, sugerindo remédios jurídicos para que o professor se contraponha a denúncias baseadas na divulgação não autorizada de gravações de suas aulas. Por fim, seguem-se as considerações finais.

\footnotetext{
${ }^{3}$ CONJUR. Deputada eleita de SC deve apagar post pedindo que alunos denunciem professores. Revista Consultor Jurídico, 1. nov. 2018. Disponível em: https://www.conjur.com.br/2018-nov-01/deputada-eleita-apagar-postpedindo-filmagem-professores. Acesso em: 26 mar. 2020.

${ }^{4}$ CONJUR. TJ-SC autoriza deputada a incentivar aluno a denunciar professor. Revista Consultor Jurídico, 25 jan. 2019. Disponível em: https://www.conjur.com.br/2019-jan-25/tj-sc-autoriza-deputada-receber-denunciasprofessores. Acesso em: 26 mar. 2020.

${ }^{5}$ LIMA, lana Gomes de; HYPOLITO, Álvaro Moreira. A expansão do neoconservadorismo na educação brasileira. Educação e Pesquisa, v. 45, 2019, p. 13.
} 


\section{PROJETO ESCOLA SEM PARTIDO E O INCENTIVO À FILMAGEM E DIVULGAÇÃO DE AULAS}

O Escola Sem Partido é uma associação fundada por Miguel Nagib em 2004, e que alcançou visibilidade nacional em 2014. O ESP, que "demonstra o crescimento das ideias neoconservadoras na educação" ${ }^{6}$, tem atuação multifacetada e multinível. Um dos principais eixos de atuação consiste no lobby que busca convencer casas legislativas nos âmbitos municipal, estadual e federal a adotar o modelo padronizado de anteprojeto de lei propagado pelo movimento. Além disso, o ESP estimula, por meio de seu site, o envio de notificações extrajudiciais a professores e escolas identificados como "doutrinadores". O estímulo à gravação de professores por parte de estudantes é um dos pontos de destaque no site do ESP, que conta com um modelo de mandado de segurança voltado a assegurar um suposto direito de gravar aulas para distribuir a terceiros, sem autorização do professor. Este último aspecto é encarado como meio para possibilitar outro eixo de atuação principal do lobby: a divulgação de denúncias de práticas de "doutrinação" em sala de aula7.

Diversas foram as tentativas de promover mudanças legislativas destinadas a criar "um detalhado sistema de controle do trabalho docente, incluindo a divulgação de um cartaz com proibições em cada sala de aula ${ }^{8}$ e pela criação de um sistema de denúncias." ${ }^{9}$ Dentre elas, merece destaque a que resultou na Lei no 7.800/2016 do Estado de Alagoas, uma vez que esta foi objeto da Ação Direta de Inconstitucionalidade (ADI) 5537 no Supremo Tribunal Federal. Em decisão liminar, o Ministro Barroso apontou a inconstitucionalidade formal e material da norma. No aspecto formal, afirmou que a temática da lei era de competência da União. No aspecto material, considerou que o nível de generalidade das vedações contidas na lei gerava risco de aplicação seletiva e parcial. "A norma é, assim, evidentemente inadequada para alcançar a suposta finalidade a que se destina: a promoção de educação sem 'doutrinação' de qualquer ordem. É tão vaga e genérica que pode se prestar à finalidade inversa: a imposição ideológica e a perseguição dos que dela divergem." Salientou, ademais:

a norma impugnada expressa uma desconfiança com relação ao professor. Os professores têm um papel fundamental para o avanço da educação e são essenciais para a promoção dos valores tutelados pela Constituição. Não se pode esperar que uma educação adequada floresça em um ambiente acadêmico hostil, em que o docente se sente ameaçado e em risco por toda e qualquer opinião emitida em sala de aula. A lei impugnada, nesta medida, desatende igualmente ao mandamento constitucional de valorização do profissional da educação escolar ${ }^{10}$.

\footnotetext{
${ }^{6}$ Ibid., p. 10.

${ }^{7}$ Cf. RATIER, Rodrigo. 14 perguntas e respostas sobre o "Escola Sem Partido", p. 30; MANHAS, Cleomar. Nada mais ideológico que "Escola Sem Partido", p. 11 e p. 26; RIBEIRO, Vera Masagão. Apresentação, p. 5. In: SOUZA, Ana Lúcia Silva et al (org.). A ideologia do movimento Escola Sem Partido: 20 autores desmontam o discurso. São Paulo: Ação Educativa, 2016

${ }^{8}$ Ver, a esse respeito, a análise presente em SANTOS, Tiago Ribeiro; CERVI, Gicele Maria. D. Quixote contra os moinhos: um ensaio sobre o Movimento Escola Sem Partido. Ensaio: Avaliação e Políticas Públicas em Educação, v. 27, n. 105,2019 , p. 712-731.

${ }^{9}$ XIMENES, Salomão. O que o direito à educação tem a dizer sobre "Escola Sem Partido"? In: SOUZA, Ana Lúcia Silva et al (org.). Op. cit., p. 52.

10 SUPREMO TRIBUNAL FEDERAL. Medida cautelar na ação direta de inconstitucionalidade 5.537 / Alagoas. Relator: Ministro Luís Roberto Barroso. Brasília: 21 mar. 2017. Disponível em: https://portal.stf.jus.br/processos/downloadPeca.asp?id=311456113\&ext=.pdf. Acesso em: 26 mar. 2020.
} 
Embora a decisão judicial apontada sinalize, em sede liminar, as perspectivas de insucesso das inovações legislativas pretendidas pelo ESP, em razão de vícios de inconstitucionalidade, não se pode desprezar que o lobby obteve "recente sucesso em pautar o debate público nacional" ${ }^{11}$, tendo chegado a tornar-se um dos interlocutores do Ministério da Educação ${ }^{12}$. Nesse sentido, mais do que uma disputa pelo formato assumido pelas políticas públicas de educação, a envolver poderes Legislativo, Executivo, Judiciário e o Ministério Público, o ESP busca alcançar seus objetivos por meio da disputa cultural. De fato, a atuação do ESP adquiriu relevante presença em redes sociais, de modo que "a disputa em torno do currículo educacional no Brasil transbordou os meios pedagógicos e jurídicos especializados, transformando-se em pauta populista e de senso-comum eleitoral, inclusive"13. Os objetivos de "limitar aprioristicamente a liberdade de ensinar, além de vedar o desenvolvimento de políticas públicas educacionais nos campos de gênero, sexualidade e formação cidadã" ${ }^{14}$ e de instaurar nas salas de aula uma "censura ativa, de proibição a priori" ${ }^{15}$ podem ser alcançados, ao menos em parte, para além das movimentações institucionais formais.

As representações do ESP estimulam a compreensão da figura do professor como inimigo. Para Carl Schmitt, o critério de demarcação do "político" está justamente na relação amigo-inimigo. "A contraposição política é a contraposição mais intensa e extrema, e toda dicotomia concreta é tão mais política quanto mais ela se aproxima do ponto extremo, o agrupamento do tipo amigo-inimigo." ${ }^{16}$ Schmitt aponta ainda que, em situações críticas, a necessidade de "pacificação intraestatal", e portanto de unidade, leva a que o Estado determine o "inimigo interno"17. A caracterização do professor como este inimigo interno exerce o importante papel de forjar a unidade política pelo estímulo à luta a um inimigo comum.

Nesse sentido, o lobby e seus seguidores pretendem "criar um ambiente de ódio em relação aos professores e deixá-los com medo de fazer o seu trabalho de acordo com seu saber profissional." ${ }^{18} \mathrm{Um}$ dos meios para fazê-lo consiste em fazer referência aos educadores brasileiros como um "exército organizado de militantes travestidos" ${ }^{19}$. Para essa concepção, os "professores doutrinadores" são "algozes" e os estudantes são as "vítimas" ${ }^{20}$. Nesse eixo, são utilizados termos genéricos para "enquadrar" professores: "doutrinação ideológica", "ideologia de gênero" e "marxismo cultural" ${ }^{21}$. O resultado é a representação do professor,

\footnotetext{
${ }^{11}$ XIMENES, Op. cit., p. 50.

12 LIMA; HYPOLITO, Op. cit., p. 12

${ }^{13}$ SEVERO, Ricardo Gonçalves; GONÇALVES, Suzane da Rocha Vieira; ESTRADA, Rodrigo Duque. A Rede de Difusão do Movimento Escola Sem Partido no Facebook e Instagram: conservadorismo e reacionarismo na conjuntura brasileira. Educação \& Realidade, v. 44, n. 3, 2019, p. 23.

${ }^{14}$ XIMENES, Op. cit., p. 50.

15 Ibid., p. 52.

${ }^{16}$ SCHMITT, Carl. O conceito do político. Belo Horizonte: Del Rey, 2008, p. 31.

17 Ibid., p. 49.

18 PENNA, Fernando. O ódio aos professores. In: SOUZA, Ana Lúcia Silva et al (org.). A ideologia do movimento Escola Sem Partido: 20 autores desmontam o discurso. São Paulo: Ação Educativa, 2016, p. 94.

${ }^{19}$ LIMA; HYPOLITO, Op. cit., p. 10

${ }^{20}$ MANHAS, Cleomar. Nada mais ideológico que "Escola Sem Partido" In: SOUZA, Ana Lúcia Silva et al (org.). Op. cit., p. 19. Para uma análise de adjetivações utilizadas de modo associado à figura do professor em projetos de lei correlatos ao ESP, Cf. DALTOÉ, Andréia da Silva; FERREIRA, Ceila Maria. Ideologia e filiações de sentido no Escola Sem Partido. Linguagem em (Dis)curso-LemD, v. 19, n. 1, 2019, p. 209-227.

${ }^{21}$ PENNA, Op. cit., p. 94.
} 
A aula como objeto da proteção dos direitos de autor: um guia para professores contra a divulgação não autorizada de suas aulas

de escolas e universidades como ameaças a crianças e jovens, como espaços de "corrupção dos inocentes"22.

Diante de tal cenário, o ESP estimula uma "cultura da delação"23. "A promoção do papel ativo dos estudantes na defesa de seus direitos, afirmado pelo ESP, resume-se, na verdade, ao papel de denúncia de seus professores; em outras palavras, ao papel de dedoduro"24. Na construção do professor como inimigo público, aquele a quem cabe delatar e denunciar, alcança-se a "criminalização do trabalho pedagógico" 25: ainda que esta não tenha sido obtida por inovação institucional formal, ela gera efeitos em termos de uma cultura persecutória nas salas de aula e também em termos de autocontenção ou autocensura por parte de docentes. No fundo, porém, a "censura aos professores implica a negação do direito à educação aos estudantes jovens" 26 .

A cultura da delação assim instaurada seria, segundo essa visão, justificável para preservar a "neutralidade" do professor em sala de aula frente a uma "audiência cativa" de estudantes. "Ora, o que significa neutralidade para os partidários do Escola Sem Partido? Para eles, neutralidade é sinônimo do enquadramento do professor aos pensamentos e crenças dos pais dos alunos." ${ }^{27}$ O lobby político do ESP se apresenta como "apartidário" 28 , mas há o "claro propósito de contribuir para que alguns princípios defendidos por autores considerados de esquerda sejam de alguma forma criminalizados e tidos como material ideológico que atenta contra crianças e jovens." 29 Por exemplo:

Eixos temáticos como estudos de gênero, das diversidades socioculturais, debates sobre os direitos de minorias sociais, direitos humanos, história e cultura afro-brasileiras e indígenas, relações de poder e desigualdades sociais, conteúdos políticos - entre outros, que compõem em grande medida o currículo da disciplina de Sociologia - são frequentemente criticados e associados à noção de doutrinação ideológica nas publicações realizadas pela página da $\operatorname{ESP}(\ldots)^{30}$

A apresentação do ESP como "apartidário" por seus partidários é uma tentativa de encobrir sua forte proposta de negação do pluralismo político afirmado como fundamento da República no primeiro artigo da Constituição de 1988. O ESP busca promover o que Carl Schmitt se refere como "despolitização". Mas Schmitt o faz de maneira crítica e cética: para ele, nada escapa do domínio político. "Na verdade, [...] é uma forma típica e especialmente intensa de fazer política apresentar o oponente como político a si mesmo como apolítico (i.e., aqui: científico, justo, objetivo, imparcial etc.)." ${ }^{31} \mathrm{O}$ movimento, no fundo, "utiliza-se de uma

\footnotetext{
22 Ibid., p. 98.

${ }^{23}$ GADOTTI, Moacir. A Escola Cidadã frente à "Escola Sem Partido". In: SOUZA, Ana Lúcia Silva et al (org.). Op. cit., p. 151.

${ }^{24}$ FREITAS, Maria Virgínia de. Jovens, escola democrática e proposta do "Escola Sem Partido". In: SOUZA, Ana Lúcia Silva et al (org.). Op. cit., p. 106.

${ }^{25}$ GADOTTI, Op. cit., p. 152.

${ }^{26}$ FREITAS, Op. cit., p. 107.

${ }^{27}$ VASCONCELOS, Joana Salém. A escola, o autoritarismo e a emancipação. In: SOUZA, Ana Lúcia Silva et al (org.). Op. cit., p. 80.

${ }^{28}$ RATIER, Op. cit. p. 33.

${ }^{29}$ CATELLI JR, Roberto. A criminalização ideológica dos livros didáticos: a quem serve? In: SOUZA, Ana Lúcia Silva et al (org.). Op. cit., p. 90.

${ }^{30}$ OLIVEIRA, Ana Cláudia Rodrigues de; STORTO, Letícia Jovelina; LANZA, Fabio. A educação básica brasileira em disputa: doutrinação versus neutralidade. Rev. Katálysis, v. 22, n. 3, 2019, p. 472.

${ }^{31}$ SCHMITT, Op. cit., p. 21.
} 
falsa neutralidade e apartidarismo para questionar as escolas e seus professores e difundir concepções conservadoras"32.

\section{DIREITOS DE AUTOR: REPRODUÇÃO DE AULAS GRAVADAS E DIREITOS PATRIMONIAIS DO PROFESSOR}

A presente seção discute aspectos jurídicos correlatos que buscam situar o ato da divulgação não autorizada de aulas gravadas no tratamento conferido pelos direitos de autor. Num primeiro momento, a subseção 2.1 aborda aspectos do direito autoral, de direitos de autor e dos direitos conexos. Em seguida, a subseção 2.2 levanta a diferenciação entre "coisas" e "não coisas" para apontar aspectos personalíssimos atribuíveis dos direitos autorais, em contraste com aspectos patrimoniais. Por sua vez, a subseção 2.3 aborda a proteção jurídica da aula como direito personalíssimo do professor.

\subsection{Direito autoral, direitos de autor e direitos conexos}

A abordagem de direito autoral, direitos de autor e direitos conexos está diretamente ligada ao direito à propriedade. O Código Civil brasileiro classificou o direito de propriedade como sendo um direito real e no artigo 1.228 definiu o proprietário como "aquele que tem a faculdade de usar, gozar e dispor da coisa, e o direito de reavê-la do poder de quem quer que injustamente a possua ou detenha". A aplicação da noção de propriedade simultaneamente a bens corpóreos e incorpóreos se torna "difícil e árdua", nos dizeres de Carlos Roberto Gonçalves,

[...] a tarefa de conceituar a propriedade. Esta 'mais se sente do que se define', na expressão de Caio Mario da Silva Pereira, visto que 'a ideia de 'meu e teu', a noção do assenhoramento de bens corpóreos e incorpóreas independe do grau de conhecimento ou do desenvolvimento intelectual'. A própria origem do vocábulo é obscura, entendendo alguns que vem do latim proprietas, derivado de proprius, designando o que pertence a uma pessoa. Assim, a propriedade indicaria toda relação jurídica de apropriação de um certo bem corpóreo ou incorpóreo. ${ }^{33}$

Não menos importante é à disposição de que "a propriedade presume-se plena e exclusiva, até prova em contrário" (Art. 1.231 do Código Civil), ou seja, trata-se de um direito real cujos limites somente podem ser dados pela legalidade estrita afinal não se pode limitar tal direito por qualquer ação, interpretação, analogia que não estejam de modo claro.

No mesmo sentido, "os frutos e mais produtos da coisa pertencem, ainda quando separados, ao seu proprietário, salvo se, por preceito jurídico especial, couberem a outrem". (Art. 1.232 do Código Civil). Portanto, o direito privado que tem no Código Civil um dos seus

\footnotetext{
32 SEVERO; GONÇALVES; ESTRADA, Op. cit., p. 11

${ }^{33}$ GONÇALVES, Carlos Roberto. Direito civil brasileiro: Direito das coisas. 12. ed. Saraiva: São Paulo, 2017. v. 5, p. 224.
} 
A aula como objeto da proteção dos direitos de autor: um guia para professores contra a divulgação não autorizada de suas aulas

sustentáculos dispôs sobre especial proteção ao direito de propriedade e ao seu gozo exclusivo pelo proprietário.

Ratifica esse entendimento a lição de Newton Silveira de que "cabe ao autor o direito exclusivo de utilizar, fruir e dispor da obra literária, artística ou científica" - a definição romana do direito de propriedade: ius utendi, fruendi et abutendi. ${ }^{34}$ A Constituição Federal, especialmente no Art. 5으, elevou o direito de propriedade ao patamar de garantia individual e, portanto de cláusula pétrea. Merecem destaque os seguintes incisos:

XXII - é garantido o direito de propriedade;

$[\ldots]$

XXVII - aos autores pertence o direito exclusivo de utilização, publicação ou reprodução de suas obras, transmissível aos herdeiros pelo tempo que a lei fixar;

$[\ldots]$

XXVIII - são assegurados, nos termos da lei:

a) a proteção às participações individuais em obras coletivas e à reprodução da imagem e voz humanas, inclusive nas atividades desportivas;

b) o direito de fiscalização do aproveitamento econômico das obras que criarem ou de que participarem aos criadores, aos intérpretes e às respectivas representações sindicais e associativas.

Posterior ao texto constitucional, a Lei №. 9.610/1998 definiu o que são as obras intelectuais:

Art. 70 São obras intelectuais protegidas as criações do espírito, expressas por qualquer meio ou fixadas em qualquer suporte, tangível ou intangível, conhecido ou que se invente no futuro.

O termo "intangível" merece destaque, uma vez que deixa explícito, em conformidade com a Constituição Federal, que a proteção da propriedade não se limitará à propriedade material, mas abrange também a criação humana como fruto da capacidade de pensar em abstrato. Ainda quanto ao artigo 70 da Lei 9.610/1998 e sua relação com o trabalho docente, é importante destacar dois incisos que definem como obras intelectuais:

XI - as adaptações, traduções e outras transformações de obras originais, apresentadas como criação intelectual nova;

[...]

XIII - as coletâneas ou compilações, antologias, enciclopédias, dicionários, bases de dados e outras obras, que, por sua seleção, organização ou disposição de seu conteúdo, constituam uma criação intelectual.

Logo, a propriedade demonstra uma dimensão que supera a sua dimensão material, pois "[n]o passado próximo, só se falava em propriedade material, portanto era comum pensar em transferência de propriedade material, em venda, cessão, locação de bens

\footnotetext{
${ }^{34}$ SILVEIRA, Newton. Propriedade intelectual: propriedade industrial, direito de autor, software, cultivares, nome empresarial, título de estabelecimento, abuso de patentes. 6 ed.. Barueri: Manole, 2018, p. 56.
} 
materiais, como uma cadeira, uma casa, etc." ${ }^{35}$ A produção literária, por exemplo, é merecedora de toda a proteção jurídica necessária para resguardar os direitos do autor, seja originário ou derivado. Nesse caso, o objeto da proteção não é o suporte, como o livro, mas a manifestação do espírito, a manifestação artística impressa na obra. O mesmo vale para uma tela, um CD etc. ${ }^{36}$ Nesse sentido, no caso da propriedade imaterial produzida pelo trabalho docente, não será meramente a aula como aspecto físico/material que será protegida, mas sim a sua dimensão quanto manifestação do espírito do professor.

A propriedade intelectual é necessariamente uma expressão da propriedade imaterial. Os direitos autorais, por sua vez, são espécie desse gênero. É possível traçar um panorama para situar a inserção dos direitos de autor como objeto de proteção. Num primeiro agrupamento, correspondente aos "direitos autorais", encaixam-se: a) direitos de autor; b) direitos conexos; e c) programas de computador. Um segundo agrupamento é referido à "propriedade industrial", e compreende a proteção a d) desenhos industriais; e) indicações geográficas; f) marcas; e g) patentes. Por fim, o terceiro grupo corresponde às "proteções sui generis", de modo a englobar: h) cultivares; i) topografia; e j) conhecimentos tradicionais ${ }^{37}$. A análise aqui feita restringe-se ao aspecto dos direitos de autor e direitos conexos.

O Direito Autoral compreende todo o complexo de normas jurídicas que regem as relações e as consequências pertinentes à concepção de obras intelectuais artísticas, científicas e literárias oriundas de criações do espírito, devidamente exteriorizadas e afixadas num suporte tangível ou intangível. Isto é, são as normas que vão estabelecer quais criações serão passíveis de gerar direitos ao seu criador e/ou titular, e quais direitos e modalidades de exploração econômica serão ${ }^{38}$.

Direito do autor é o direito que todo criador de uma obra intelectual tem sobre a sua criação. Esse direito é personalíssimo, exclusivo do autor (art. 5. ․, XXVII, da Constituição Federal). Constitui-se de um direito moral ${ }^{39}$ (aspecto da criação) e um direito patrimonial (aspecto pecuniário). Está definido por vários tratados e convenções internacionais, dentre os quais o mais significativo é a Convenção de Berna. No Brasil, a Lei no 9.610 de 19 de fevereiro de 1998 alterou, atualizou e consolidou a legislação sobre direitos autorais.

No ordenamento brasileiro, existe uma separação entre o direito do autor e direito autoral. Logo, direito do autor é o ramo do ordenamento jurídico que regulamenta a atribuição de direitos ligados ou relativos a obras literárias e artísticas, já o direito autoral

\footnotetext{
35 PANZOLINI, Carolina; DEMARTINI, Silvana. Manual de direitos autorais. Brasília: Tribunal de Contas da União, Secretaria-Geral de Administração, 2017, p. 13

${ }^{36}$ Ibid., p. 14

37 Ibid., p. 14

38 Ibid., p. 14.

39 Lei no 9.610/1998: Art. 24. São direitos morais do autor: I - o de reivindicar, a qualquer tempo, a autoria da obra; II - o de ter seu nome, pseudônimo ou sinal convencional indicado ou anunciado, como sendo o do autor, na utilização de sua obra; III - o de conservar a obra inédita; IV - o de assegurar a integridade da obra, opondose a quaisquer modificações ou à prática de atos que, de qualquer forma, possam prejudicá-la ou atingi-lo, como autor, em sua reputação ou honra; V - o de modificar a obra, antes ou depois de utilizada; VI - o de retirar de circulação a obra ou de suspender qualquer forma de utilização já autorizada, quando a circulação ou utilização implicarem afronta à sua reputação e imagem; VII - o de ter acesso a exemplar único e raro da obra, quando se encontre legitimamente em poder de outrem, para o fim de, por meio de processo fotográfico ou assemelhado, ou audiovisual, preservar sua memória, de forma que cause o menor inconveniente possível a seu detentor, que, em todo caso, será indenizado de qualquer dano ou prejuízo que lhe seja causado.
} 
A aula como objeto da proteção dos direitos de autor: um guia para professores contra a divulgação não autorizada de suas aulas

engloba, além disso, os direitos conexos, como os direitos dos artistas intérpretes ou executantes, dos produtores de fonogramas e dos organismos de radiodifusão.

Nos termos do art. 22 da Lei no 9.610 de 19/02/98, "pertencem ao autor os direitos morais e patrimoniais sobre a obra que criou". Enquanto o direito moral assegura a autoria da criação ao autor da obra intelectual, o chamado direito patrimonial regula a utilização econômica desta obra. Sequencialmente aparecem os direitos conexos, que se ligam aos direitos dos artistas intérpretes ou executantes, dos produtores fonográficos e dos organismos de radiodifusão. Os direitos conexos são direitos paralelos aos direitos autorais, sendo referidos aos que trabalham ou contribuem para a difusão ou disseminação das obras e criações do espírito. Ademais, a Lei no. 9.610/1998 estendeu a proteção dada aos direitos do autor para os direitos conexos.

\title{
2.2 Direitos autorais como direitos personalíssimos: entre coisas e não-coisas
}

Foram diversas as concepções que buscaram explicar a natureza jurídica dos direitos autorais. Entre elas, por algum tempo, figurou a compreensão de que os direitos autorais seriam direitos reais - como direito de propriedade imaterial. Porém, essa compreensão viria a ser superada por aquela que passou a entender que a natureza jurídica dos direitos autorais é de direitos da personalidade e, justamente por isso devem ser considerados direitos personalíssimos do autor.

Referido aspecto desperta a reflexão sobre as categorias de coisas e não-coisas, como desdobramentos da propriedade material e imaterial, respectivamente. Analisando esse fenômeno, mas com foco na informática, Tercio Sampaio Ferraz Junior traz algumas reflexões importantes para o raciocínio proposto na presente subseção:

\begin{abstract}
A dificuldade em tratar o software como res ou mesmo como coisa incorpórea ou ainda como objeto imaterial permite uma rápida incursão semântica. A palavra latina materia resulta da tentativa dos romanos de traduzir a hylé grega, que, originariamente, significava madeira (wood, timber, lumber, Holz, Bauholz). O termo espanhol madera (em português: madeira) é uma reminiscência desse uso da palavra latina (materia). Na verdade tratava-se da madeira estocada nas oficinas dos carpinteiros. Nesse sentido, algo amorfo (de morphé), à espera da forma que lhe seria dada pelo carpinteiro. A dualidade forma-matéria lembra, assim, a expressão Stoff, do verbo stopfen, como um mundo (stoffliche Welt) que só se realiza ao tornar-se o preenchimento de algo. Donde o mundo material como aquilo que preenche as formas (stoffing). A palavra correspondente em francês é farce (Füllsel, Füllung, farcing), donde a possibilidade de se entender o mundo material (stofflich) como Farce (farce)..$^{40}$
\end{abstract}

\footnotetext{
40 FERRAZ JUNIOR, Tércio Sampaio. A erosão dos direitos subjetivos por força do desenvolvimento técnico (patentes, direito de autor). In: BAPTISTA, Luiz Olavo; FERRAZ JÚNIOR, Tércio Sampaio. Novos Caminhos do Direito no Século XXI: Direito Internacional, Filosofia Jurídica e Política, Dogmática Jurídica e Direitos Fundamentais. 2 ed. Curitiba: Juruá, 2013, p. 458.
} 
Assim, por exemplo, na medida em que o carpinteiro dava forma à madeira, ocorriam duas construções simultâneas: a primeira fazia com que surgisse o objeto cadeira e a segunda era o próprio carpinteiro, pois é acertada a compreensão de que o operário faz a coisa e a coisa faz o operário, como no poema 0 operário em construção, de Vinícius de Moraes $^{41}$.

Dessa forma, sobretudo quando se considera que o processo de produção da propriedade intelectual/imaterial do professor envolve múltiplos momentos ${ }^{42}$, é necessário estabelecer a analogia com o trecho citado acima, ou seja, o processo que antecede a aula nada mais é do que a madeira estocada à espera de que o carpinteiro lhe dê forma.

E essa compreensão se coaduna com uma constatação bastante complexa do trabalho docente que é a seguinte: uma aula ministrada jamais poderá ser repetida. Não pode ser repetida pelo docente que a ministrou e muito menos por um discípulo, outro docente, ou quem quer que seja. É única, exclusiva. A aula corresponde a um direito personalíssimo do professor porque se o trabalho empenhado para a produção intelectual da aula for substituído, resultará em um produto diverso, ainda que esse produto também tenha suas peculiaridades.

Contribui ainda para reforçar a aula como direito personalíssimo do professor o fato de que a aula esconde seu processo de criação. Não se pode esquecer que o professor se faz professor na medida em que estuda, planeja e se engaja na relação de ensino-aprendizagem com um público específico.

O que aqui se aponta como personalíssimo é o aspecto moral da criação ou o chamado direito de autor originário ${ }^{43}$. Porém, juridicamente, é certo que os aspectos pecuniários atrelados aos direitos de autor - que envolvem o aspecto derivado ${ }^{44}$ - são passíveis de transferência, nos termos do art. 49 da Lei no 9.610/1998:

Os direitos de autor poderão ser total ou parcialmente transferidos a terceiros, por ele ou por seus sucessores, a título universal ou singular, pessoalmente ou por meio de representantes com poderes especiais, por meio de licenciamento, concessão, cessão ou por outros meios admitidos em Direito, obedecidas as seguintes limitações:

I - a transmissão total compreende todos os direitos de autor, salvo os de natureza moral e os expressamente excluídos por lei

Porém, o aspecto moral ou originário do direito de autor não deixa de ser personalíssimo pela possibilidade de se realizar a transferência do aspecto patrimonial ou derivado desse direito moral (criação). Referida diferenciação é reforçada pelo paralelo

\footnotetext{
41 MORAES, Vinícius de. O operário em construção. Rio de Janeiro, 1959. Disponível em: http://www.viniciusdemoraes.com.br/pt-br/poesia/poesias-avulsas/o-operario-em-construcao. Acesso em: 26 mar. 2020.

${ }^{42}$ São momentos deste processo, por exemplo: criação de um curso; definição das disciplinas; construção de ementa e bibliografia; escolha do docente; matricula de alunos; estabelecimento de local e calendário; planejamento do curso da disciplina; definição da bibliografia; preparação da aula (pensando em si, na mensagem, e nos estudantes); utilização de sua imagem, voz, capacidade de análise, e de resposta a eventuais indagações etc.

${ }^{43}$ PANZOLINI; DEMARTINI, Op. cit., p. 52

${ }^{44}$ Ibid., p. 52
} 
A aula como objeto da proteção dos direitos de autor: um guia para professores contra a divulgação não autorizada de suas aulas

traçado por José de Oliveira Ascensão entre a titularidade dos direitos de autor e o direito ao nome:

Poderá o criador intelectual despojar-se do seu direito, de tal modo que ele surja desde o início da titularidade de terceira pessoa? Neste caso, o criador intelectual nunca seria, juridicamente, autor. O problema é conexo com outro que com ele por vezes se confunde, e tem sido considerado pela doutrina brasileira: o da cedência do direito ao nome. Em todo o caso, em rigor, na cedência já não haveria atribuição originária, pois o direito teria nascido na titularidade do criador intelectual, que só depois se desfaria dele: haveria pois transmissão. ${ }^{45}$

E prossegue:

\begin{abstract}
A aquisição originária do direito de autor por terceiro representa como que um plus em relação à cedência do direito ao nome. Por outro lado, no tratamento do tema estarão necessariamente implicados aspectos ligados à personalidade do autor. [...] Concluiremos que hoje em dia não é possível a cedência definitiva do direito ao nome. A serem admissíveis contratos pelos quais o criador intelectual autoriza outrem a arrogar-se publicamente essa qualidade, nem por isso o direito à paternidade de obra se perde: o criador intelectual pode a todo tempo tornar pública a sua qualidade e vir reclamar a autoria. Há, pois, um núcleo, ligado à personalidade do agente, que se não perde nunca. [...] E será então possível estipular-se que a obra pertencerá originariamente a pessoa diferente do criador intelectual? Poderia, sustentarse a negativa, invocando o direito pessoal do autor de 'reivindicar, a qualquer tempo, a paternidade da obra'. ${ }^{46}$
\end{abstract}

Dessa forma, percebe-se que, embora seja possível a transferência dos aspectos derivados - e portanto patrimoniais - dos direitos de autor, seu aspecto moral, de criação ou originário - permanece personalíssimo.

\title{
2.3 A proteção jurídica da aula como direito personalíssimo do professor
}

A partir dos elementos abordados na subseção anterior, é possível compreender que o professor enquadra-se perfeitamente no conceito legal previsto na Lei no 9.610/1998: "Art. 11. Autor é a pessoa física criadora de obra literária, artística ou científica." Ademais, o professor, como autor de propriedade intelectual, goza da proteção independentemente de registro de sua obra, ou seja, se fosse possível registrar suas aulas o professor teria a proteção legal mesmo que não as registrasse: "Art. 18. A proteção aos direitos de que trata esta Lei independe de registro".

Como proprietário do que se origina do seu trabalho, o professor goza de todas as garantias legais possíveis e necessárias para a proteção de sua obra intelectual/imaterial, conforme a previsão de proteção dos direitos morais e patrimoniais do autor (Arts. 24 a 45 da

\footnotetext{
${ }^{45}$ ASCENSÃO, José de Oliveira. Direito Autoral. 2. ed. Rio de Janeiro: Renovar, 1997. p. 109

${ }^{46}$ Ibid., p. 110.
} 
Lei no 9.610/1998). Além disso, o Artigo 46 de referida lei reforça a proteção específica à aula como criação do professor:

Art. 46. Não constitui ofensa aos direitos autorais: (...) IV - o apanhado de lições em estabelecimentos de ensino por aqueles a quem elas se dirigem, vedada sua publicação, integral ou parcial, sem autorização prévia e expressa de quem as ministrou. (ênfase acrescentada).

Ou seja, sem autorização prévia e expressa do professor, a Lei 9.610 proíbe a publicação integral ou parcial de apanhado de lições: não importa o suporte - se em um caderno, um texto em blogue, um áudio contido em um gravador ou um vídeo capturado por meio de um aparelho de celular.

Outros incisos do Art. 46 da Lei 9.610 precisam ser considerados. Nos termos do inciso II, não constitui violação de autor "a reprodução, em um só exemplar de pequenos trechos, para uso privado do copista, desde que feita por este, sem intuito de lucro"

A par do que não se considera obra protegida (art. 8ㅇ), a Lei de Direitos Autorais mantém as limitações elencadas no art. 48 da Lei de 1973, sendo mais severa com as citações e a reprografia. Assim é que o uso privado passa a ser limitado à 'reprodução, em um só exemplar de pequenos trechos, para uso privado do copista, desde que feita por este, sem intuito de lucro' (art. 46, II). ${ }^{47}$

Percebe-se, portanto, que o apanhado de lições, em qualquer suporte, para uso privado do estudante, não chega a caracterizar, em si, a violação a direitos de autor do professor. Porém, o problema proposto pelo presente ensaio é a divulgação não autorizada da aula gravada - prática esta incentivada pelo ESP ${ }^{48}$. Essa última hipótese se enquadra no inciso IV, já mencionado, e não no inciso II do Art. 46, visto que, nesse caso, não se destina a "uso privado do copista". ${ }^{49}$

Ainda outro ponto a considerar é o inciso III do Art. 46 da Lei 9.610, segundo o qual não configura violação a direitos de autor: "a citação em livros, jornais, revistas ou qualquer outro meio de comunicação, de passagens de qualquer obra, para fins de estudo, crítica ou polêmica, na medida justificada para o fim a atingir, indicando-se o nome do autor e a origem da obra."

Considerado de forma isolada, o dispositivo acima poderia ensejar a dispensa da autorização do professor para fins de reprodução de sua aula gravada. No entanto, verifica-se

\footnotetext{
47 SILVEIRA, Op. cit., p. 57.

48 O foco do presente artigo não é o ato isolado da gravação, mas a distribuição, a terceiros, e sem autorização expressa do professor, de gravações de suas aulas. Os atos de gravar e repassar sem autorização são trabalhados em conjunto apenas na medida em que o primeiro é pressuposto do último. A ilegalidade consiste no ato de repassar adiante a gravação da aula sem autorização prévia e expressa de quem a ministrou.

${ }^{49}$ Fortalece o disposto no artigo 46, IV da Lei no 9.610/1998, o Código Civil em seus artigos 1.231 e 1.232. Art. 1.231: "A propriedade presume-se plena e exclusiva, até prova em contrário." Art. 1.232. "Os frutos e mais produtos da coisa pertencem, ainda quando separados, ao seu proprietário, salvo se, por preceito jurídico especial, couberem a outrem".
} 
A aula como objeto da proteção dos direitos de autor: um guia para professores contra a divulgação não autorizada de suas aulas

que os dispositivos contidos nos incisos III e IV se chocam, de modo a configurar uma antinomia. ${ }^{50}$ Nesse caso, confrontam-se uma norma de caráter geral e outra de caráter especial. A regra do inciso III é mais geral: abrange "passagens de qualquer obra", e autoriza a divulgação para fins de estudo, crítica ou polêmica. Já a regra do inciso IV é mais específica: refere-se somente ao "apanhado de lições em estabelecimentos de ensino", e condiciona sua reprodução à autorização prévia e expressa do professor. Nesse caso, a solução do conflito aparente das normas se dá por meio do "critério de especialidade", que:

\begin{abstract}
é aquele com base em que, de duas normas incompatíveis, uma geral e uma especial (ou excepcional), prevalece a segunda: lex specialis derogat generali. Também nesse caso a razão do critério não é obscura: lei especial é aquela que derroga uma lei mais geral, ou seja, que subtrai a uma norma uma parte da sua matéria para submetê-la a uma regulamentação diversa (contrária ou contraditória). ${ }^{51}$
\end{abstract}

A prevalência da necessidade de autorização prévia e expressa do professor para que a reprodução da aula possa ocorrer, conforme estabelecido pelo Art. 46, IV, da L. 9610, reforça a noção de que a apropriação e desapropriação, como elementos fundamentais para a transferência da propriedade, somente são possíveis no mundo do dever ser. Tal afirmação deve ser entendida como consectária da noção rousseauniana de que a força - ou seja, um aspecto meramente fático - não serve de fundamento para a obediência e, portanto, não fundamenta o exercício da autoridade. Ele questiona: "Se um assaltante me surpreender num canto do bosque não somente será necessário, por força, que eu lhe entregue a bolsa como, se puder ocultá-la, não estarei em sã consciência obrigado a entregá-la, já que, afinal, a pistola que ele empunha é também um poder?" A isso, responde: “O mais forte jamais é bastante forte para ser sempre o senhor se não transformar sua força em direito e a obediência em dever. [...] A força é um poder físico; não vejo, de modo algum, que moralidade pode resultar de seus efeitos. Ceder à força é um ato de necessidade, não de vontade; é, no máximo, um ato de prudência, em que sentido poderá ser um dever?"

E arremata: "Convenhamos, então, que a força não produz o direito e que não se está obrigado a obedecer senão aos poderes legítimos [...]"52 Daí a noção de que o apropriarse e o desapropriar-se decorrem de formulações no mundo do dever ser. Ou seja, somente pode ocorrer por intermédio do contrato ${ }^{53}$ que necessariamente conterá a autorização do proprietário genuíno que permitirá a cessão de sua propriedade imaterial, que no caso referese ao professor a partir do momento em que a propriedade corresponde à sua própria essência manifestada na forma de produção intelectual.

Neste sentido, o estímulo à divulgação não autorizada de gravações de aulas, além de ferir seu direito de autor e consequentemente sua propriedade intelectual/imaterial, ainda afeta diretamente a forma como o professor passará a se relacionar com o mundo, pois a propriedade, em aspecto amplo, traduz em última análise a forma pela qual o indivíduo se

\footnotetext{
${ }^{50}$ Ver BOBBIO, Norberto. Teoria Geral do Direito. São Paulo: Martins Fontes, 2010, p. 240.

51 Ibid., p. 253.

52 ROUSSEAU, Jean-Jacques. Do contrato Social. São Paulo: Folha de São Paulo, 2010, p. 25.

53 Cabe, a esse respeito, uma ressalva: a delimitação proposta para o presente artigo não compreende as hipóteses em que professores laborem mediante relações contratuais que tenham previsto, de modo expresso, a transferência dos aspectos derivados do direito de autor à instituição de ensino.
} 
relaciona com o mundo. A captura fática da aula em um suporte específico - seja áudio, vídeo ou ambos - e sua divulgação de modo algum fundamentam a transferência da propriedade sobre a criação intelectual. Como dito, referida transferência apenas pode ocorrer no campo do dever ser, ainda que se refira a uma propriedade imaterial.

Cabe lembrar que o mundo no qual nos relacionamos foi inicialmente o mundo de coisas materiais. Este definiu o modo como o homem se relacionava, exteriorizava a sua essência, em meio a coisas concretas, materiais. Porém, vivemos um momento em que as não-coisas passaram a influir diretamente na nossa maneira de relação com o mundo, agora mais amplo, pois é composto não só de coisas, mas também de não-coisas.

\begin{abstract}
Ora, a terceira, e atual revolução industrial, é a que implica a substituição das máquinas por aparelhos eletrônicos, cada vez mais miniaturizados em unidades de convergência tecnológica. [...] Nesse novo mundo, a memória do computador é uma não-coisa (Unding). Não é propriamente imaterial, porque não é propriamente consumível. Embora ainda ela exista enclausurada em coisas (chips de silício, raios laser), não é um objeto de uso. Não está ao alcance da mão (vorhanden), embora esteja disponível (zuhanden). [...] Tenhase, pois, em resumo, os elementos da condição informática: a) novo veículo: meio informático (aparelho eletrônico); b) nova forma de reprodução: digitalização; c) sistema de comunicação instantâneo e global; d) um ser humano "aparelhado" (Apparatmensch). Segue daí a descoisificação (Verundinglichung) das criações intelectuais/imateriais em termos informáticos: bit como suporte intangível. Na verdade, a noção de intangibilidade é inadequada, pois construída a partir da percepção fisicamente nuclear da realidade. Propriamente, o bit não é a negação do tangível (tangere como tocar com os dedos). Por isso se fala de não-coisa (Unding). O termo vulgarizado para expressar esse novo estado ou forma de ser, é virtual. ${ }^{54}$
\end{abstract}

Dessa forma, a propriedade imaterial/intelectual do professor está inserida nesta terceira fase da revolução industrial e justamente por isso o professor atua e se relaciona conforme a capacidade do aparelho dos ouvintes/discentes, que, na fase do espetáculo, poderão tentar retirar-Ihe a propriedade imaterial, mediante a divulgação não autorizada de gravações de suas aulas.

Note-se: o objeto da proteção autoral é não-coisa. O suporte pode pertencer a quem captura a aula em áudio ou vídeo. Não é sobre a propriedade do gravador, do celular, computador ou câmera que reside a controvérsia. Mas sobre o que está enclausurado nessas coisas, fora do alcance da mão: a aula ali encapsulada para distribuição a terceiros.

O que fazer diante da violação dessa propriedade imaterial? Em outros termos, de modo análogo à situação proposta por Rousseau ${ }^{55}$ : e se lhe querem "tomar a bolsa no canto do bosque"? A seção 3, a seguir, procura oferecer caminhos jurídicos para a ação diante dessas situações.

\footnotetext{
${ }^{54}$ FERRAZ JUNIOR, Op. cit., p. 461-2.

${ }^{55}$ ROUSSEAU, Op. cit., p. 25.
} 


\section{RESPONSABILIDADE CIVIL POR VIOLAÇÃO DE DIREITOS DE AUTOR CORRESPONDENTES À VEICULAÇÃO NÃO AUTORIZADA DE AULAS GRAVADAS}

Como visto, a autorização do detentor do direito personalíssimo é elemento indispensável para a sua veiculação ou utilização por terceiros. Qualquer violação a essa exigência e necessidade de autorização logicamente é compreendida como descumprimento de um dever jurídico determinado por normas de direito, ou seja, como ilícita. No ordenamento jurídico brasileiro, não existe o direito de divulgar sem autorização prévia e expressa uma gravação de aula. Mas o que fazer no caso de descumprimento?

Segundo o Código Civil (artigos 186 e 187) aquele que, por ação ou omissão voluntária, negligência ou imprudência, violar direito e causar dano a outrem, ainda que exclusivamente moral, comete ato ilícito. Também configura ilicitude a ação de quem comete abuso de direito, ou seja, extrapola os limites definidos para o exercício de um direito. Diretamente vinculada à noção configuração da ilicitude é a instituição da responsabilidade civil. O Código Civil, ao discipliná-la no Art. 927, apresenta a máxima de que quem comete ato ilícito e causa dano a alguém fica obrigado a reparar esse dano.

A capacidade que cada um tem de exercer seus direitos cria uma espécie de obrigação. O sujeito de direitos tem obrigações decorrentes de sua vivência em sociedade, conforme pontua Duguit: “Concebe-se, assim, para todos a obrigação de respeitar no outro o desenvolvimento pleno de suas atividade física, intelectual e moral e nessa obrigação reside o próprio fundamento do direito, constituindo regra social" 56 .

Cada vez que um atinge o direito de outro, causando-Ihe lesão ou ameaça, o Estado deve intervir, fazendo cessar o dano causado e assegurar que o indivíduo que lesou tenha a obrigação de reparar o mal causado ${ }^{57}$. Dessa forma, a responsabilidade civil importa a obrigação que cada um tem de responder por suas condutas danosas praticadas no convívio social.

A responsabilidade civil está ligada a uma obrigação, no caso, uma obrigação gerada por uma ação ou omissão contra outrem. A ideia de reparação de dano envolve "os seguintes elementos ou pressupostos gerais da responsabilidade civil: a) conduta humana (positiva ou negativa); b) dano ou prejuízo; c) o nexo de causalidade" ${ }^{28}$. Encontrados esses três elementos, estará caracterizado o dever de indenizar.

Dessa forma, são fartos no ordenamento jurídico brasileiro os dispositivos que estabelecem o dever jurídico de respeitar as normas referentes a direito autoral para que não se incorra em prática de ato ilícito.

No entanto, como abordado na seção 1, o ESP estimula que estudantes gravem aulas de professores com o intuito veiculá-las a público, em caráter de denúncia a respeito do que entendem ser "doutrinação". Para além do aspecto persecutório envolvido nessa prática, cumpre analisar, especificamente quanto ao aspecto da propriedade, que, na ausência de prévia e expressa autorização, a divulgação de aulas gravadas viola as proteções de direito de

\footnotetext{
${ }^{56}$ DUGUIT, Leon. Fundamentos do Direito. São Paulo: Martin Claret, 2009, p. 23.

${ }^{57}$ RESEDÁ, Salomão. A função social do dano moral. Florianópolis: Conceito Editorial, 2009.

58 GAGLIANO, Pablo Stolze. PAMPLONA FILHO, Rodolfo. Novo curso de direito civil: responsabilidade civil. 2. ed. Saraiva: São Paulo, 2004, v. 3, p. 28.
} 
autor consubstanciadas na Lei 9.610/1998. O estudante que transmite a gravação de uma aula à plataforma do ESP, sem prévia e expressa autorização do professor, comete ato ilícito. Não somente o estudante, mas também a plataforma, se esta também divulgar, uma vez que a obrigação decorrente da Lei 9.610/1998 incide sobre ambos.

Uma vez ciente da divulgação não autorizada de sua aula, seja em suporte de áudio ou vídeo, o professor estará na posição jurídica de requerer, em juízo, além da cessação da divulgação, a indenização decorrente de utilização sem autorização de sua propriedade intelectual. Referida possibilidade encontra, entre seus fundamentos, o Art. 102 da Lei no 9.610/1998:

O titular cuja obra seja fraudulentamente reproduzida, divulgada ou de qualquer forma utilizada, poderá requerer a apreensão dos exemplares reproduzidos ou a suspensão da divulgação, sem prejuízo da indenização cabível.

O direito do professor de não ter sua obra utilizada fora dos limites legais traz implicações, em termos de responsabilidade civil, também para os provedores que hospedem, na internet, conteúdos em violação a seus direitos de autor, mediante comprovação de sua culpa ou dolo:

Resta claro que, sob a ótica do Marco Civil da Internet (Lei 12.695/2014), no âmbito do grande espectro da rede mundial de computadores, mais que as dos provedores de conexão, são as atividades abrigadas pelos provedores de aplicação (hospedagem, busca e conteúdo) que envolvem a responsabilização quanto às infrações legais de qualquer gênero. Nesse contexto, encontra-se evidenciado no diploma legal da internet que: a) não há qualquer ressalva em relação a efetiva responsabilização dos provedores de conteúdo (ou seja, que operam conteúdo gerado pelo próprio provedor), cabendo-lhes, portanto, sem restrições, as normas gerais de responsabilidade civil e penal, b) diversamente, no que tange aos provedores de hospedagem (que operam conteúdo gerado por terceiros) impõe a Lei 12.965/2014 a responsabilidade subjetiva - ou seja, dependente da apuração de culpa ou dolo - [... $]^{59}$

Portanto, a hipótese de divulgação não autorizada da aula do professor, abordada no presente artigo, abre possibilidade jurídica para responsabilização do estudante (ou seu responsável) que transferiu sem autorização a aula gravada, de quem a divulgou e também do provedor do sítio de internet em que a divulgação ocorreu. Sua responsabilização surge da ilicitude do ato praticado.

Do ponto de vista dos elementos da responsabilidade civil é importante dizer que a conduta humana ${ }^{60}$ está no ato de transmitir (ou enviar para que terceiro transmita) a aula gravada sem autorização do docente. 0 dano/prejuízo ${ }^{61}$ é a violação do direito de autor devido ao ilícito de divulgar, sem observar os limites impostos pela Lei no 9.610/1998, Art. 46, IV, a

\footnotetext{
${ }^{59}$ COSTA NETTO, José Carlos. Responsabilidade dos provedores de internet nas violações a direitos autorais: Análise da legislação e precedentes jurisprudenciais. Jota, 29 mar. 2019 . Disponível em: https://www.jota.info/opiniao-e-analise/artigos/responsabilidade-dos-provedores-de-internet-nas-violacoes-adireitos-autorais-29032019. Acesso em: 16 abr. 2020.

${ }^{60}$ GAGLIANO, Pablo Stolze. PAMPLONA FILHO, Rodolfo. Novo curso de direito civil: responsabilidade civil. 2. ed. Saraiva: São Paulo, 2004, p. 65

61 lbid., p. 65.
} 
A aula como objeto da proteção dos direitos de autor: um guia para professores contra a divulgação não autorizada de suas aulas

aula gravada. Por fim o nexo de causalidade ${ }^{62}$ está no fato de que o ilícito e consequente prejuízo ao direito do autor não teria ocorrido não fosse a ação expressa na conduta humana divulgar fora dos limites impostos pela lei a aula gravada.

Encontrados todos os elementos da responsabilidade civil, configura-se a possibilidade/faculdade de que o professor acione o Poder Judiciário a fim de auferir reparação contra a violação a seu direito de autor.

\begin{abstract}
Haverá o dever de indenizar sempre que for violado o direito do autor em qualquer dos seus aspectos. Indenização por dano material se o causador do dano obtiver proveito econômico com a obra do autor sem a sua autorização ou participação; indenização por dano moral se a agressão for contra os direitos morais do autor; indenização por danos morais e patrimoniais se ambos os direitos forem violados. Já se firmou a jurisprudência, como não poderia deixar de ser, no sentido de cumularem-se as indenizações por dano material e moral ocorrendo ofensa a ambos os direitos do autor. Quanto ao dano moral, entendo ser ele presumido, isto é, decorre da simples violação de qualquer um daqueles direitos morais do autor enunciados no artigo 24 da lei autoral, ainda que a violação não exponha o autor a nenhum sentimento de dor, vexame, sofrimento ou humilhação. $O$ artigo 108 da Lei Autoral serve de suporte legal para essa conclusão ao dispor: "Quem, na utilização, por qualquer modalidade, de obra intelectual, deixar de indicar ou de anunciar, como tal, o nome, o pseudônimo ou sinal convencional do autor e do intérprete, além de responder por danos morais, está obrigado a divulgar-lhes a identidade da seguinte forma: I. Tratando de empresa de radiodifusão, no mesmo horário em que tiver ocorrido a infração, por três dias consecutivos; II. Tratando-se de publicação gráfica ou fonográfica, mediante inclusão de errata nos exemplares ainda não distribuídos, sem prejuízo de comunicação, com destaque, por três vezes consecutivas em jornal de grande circulação, dos domicílios do autor, do intérprete e do editor ou produtor; III. Tratandose de outra forma de utilização, por intermédio da imprensa, na forma a que se refere o inciso anterior. ${ }^{63}$
\end{abstract}

Vale lembrar ainda que voz, imagem e trabalho intelectual integram a aula. 0 desmembramento de um desses elementos (como por exemplo, somente a divulgação da gravação da voz, ou de uma foto do quadro do professor) não retira a proteção da propriedade intelectual enquanto direito personalíssimo.

Ademais, nos termos do artigo 932, inciso I, do Código Civil, os pais respondem por "fato de terceiro" dos "filhos menores que estiverem sob sua autoridade e em sua companhia". Nesse sentido, o professor lesado pela divulgação indevida de sua aula poderá ingressar com ação de reparação civil contra: (i) o estudante, se maior ou (ii) os pais do estudante, se menor, e (iii) a plataforma virtual divulgadora. Nessa ação, poderá pleitear, além da reparação, a suspensão da divulgação, nos termos do artigo 102 da Lei 9.610/1998.

\footnotetext{
62 Ibid., p. 65.

${ }^{63}$ CAVALIERI FILHO, Sergio. Direito Autoral e Responsabilidade Civil. Revista da Escola da Magistratura do Estado do Rio de Janeiro - EMERJ. v.4, n.13, 2001, p. 45.
} 


\section{CONSIDERAÇÕES FINAIS}

O movimento "Escola Sem Partido" (ESP) consubstancia um projeto de reconfiguração cultural do papel do professor, consistente em caracterizá-lo como um "inimigo público", um perigo à formação de crianças e jovens, a ser fiscalizado, denunciado e coibido. Nessa esteira, age em diversas frentes em diversos níveis. Dentre as frentes encontram-se: (i) lobbies legislativos para adoção de anteprojeto de lei capitaneado pelo ESP; (ii) litígios judiciais e (iii) incentivos à filmagem ou gravação de aulas para instruir denúncias contra professores por aquilo que é enigmaticamente referido como "doutrinação". Os níveis compreendem os âmbitos municipal, estadual e federal. Porém, mais do que isso, busca atuar sobre cada estudante e familiares, uma vez que procura arregimentar denunciantes nesses quadros. A atuação multifrentes e multinível no ESP coloca em xeque a liberdade de expressão e de ensino-aprendizagem.

Em seus impulsionamentos, os partidários do movimento ESP desconsideram uma implicação jurídica relevante e que emerge como consequência de suas estratégias adotadas: o incentivo que o ESP faz à divulgação não autorizada de aulas gravadas viola o regime jurídico da propriedade intelectual. O ordenamento jurídico protege as aulas como propriedade autoral do professor, a que correspondem direitos morais e patrimoniais. Tal proteção jurídica significa que a circulação de vídeos e gravações de aulas, sem autorização do professor, viola direitos de autor e enseja a responsabilidade civil de quem circulou indevidamente a gravação da aula.

O estímulo a passar gravações de aulas a terceiros, sem que seja colhida a prévia e expressa autorização do professor, configura a incitação - direcionada aos estudantes em geral, inclusive aos menores de idade - à prática de condutas ilícitas. O ESP, dessa forma, incentiva que estudantes cometam infrações legais por meio da violação a dispositivos da Lei 9.610, do Código Civil e da Constituição Federal. Evidentemente, o movimento ESP não deixa claro à audiência para a qual apela os riscos envolvidos na adesão às condutas propostas.

Professores cujos direitos foram violados devem buscar as reparações materiais em sede judicial. Mesmo que a reparação pecuniária não venha a ser o objetivo final do professor em referidas situações - afinal, o valor imaterial da liberdade de cátedra pode assumir preponderância na explicação dos padrões de conduta adotados por docentes -, é ainda assim importante responder aos ataques à liberdade docente com pedidos reparatórios, de modo a onerar, e assim desincentivar, a conduta estimulada pelo lobby do ESP e de seus partidários. No fundo, o expediente do pleito judicial de reparações é uma ferramenta para a proteção da liberdade de cátedra no Brasil.

Por fim, cumpre ressaltar a existência de certa ironia. O movimento ESP, que afirma existir um "marxismo cultural" a combater nas escolas, é o mesmo que incentiva estudantes a violar a propriedade privada: uma vez que os direitos autorais correlatos à aula são propriedade do professor. 
A aula como objeto da proteção dos direitos de autor: um guia para professores contra a divulgação não autorizada de suas aulas

\section{REFERÊNCIAS}

ASCENSÃO, José de Oliveira. Direito Autoral. 2 ed. Rio de Janeiro: Renovar, 1997.

BOBBIO, Norberto. Teoria Geral do Direito. São Paulo: Martins Fontes, 2010.

CATELLI JR, Roberto. A criminalização ideológica dos livros didáticos: a quem serve? In: SOUZA, Ana Lúcia Silva et al (org.). A ideologia do movimento Escola Sem Partido: 20 autores desmontam o discurso. São Paulo: Ação Educativa, 2016, p. 83-92.

CAVALIERI FILHO, Sergio. Direito Autoral e Responsabilidade Civil. Revista da Escola da Magistratura do Estado do Rio de Janeiro - EMERJ. v.4, n. 13, 2001, p. 43-50.

CAVALIERI FILHO, Sergio. Programa de responsabilidade civil. 10. ed. São Paulo: Atlas, 2012.

CONJUR. Deputada eleita de SC deve apagar post pedindo que alunos denunciem professores. Revista Consultor Jurídico, 1. nov. 2018. Disponível em: https://www.conjur.com.br/2018nov-01/deputada-eleita-apagar-post-pedindo-filmagem-professores. Acesso em: 26 mar. 2020.

CONJUR. TJ-SC autoriza deputada a incentivar aluno a denunciar professor. Revista Consultor Jurídico, 25 jan. 2019. Disponível em: https://www.conjur.com.br/2019-jan-25/tj-sc-autorizadeputada-receber-denuncias-professores. Acesso em: 26 mar. 2020.

COSTA NETTO, José Carlos. Responsabilidade dos provedores de internet nas violações a direitos autorais: Análise da legislação e precedentes jurisprudenciais. Jota, 29 mar. 2019 Disponível em: https://www.jota.info/opiniao-e-analise/artigos/responsabilidade-dosprovedores-de-internet-nas-violacoes-a-direitos-autorais-29032019. Acesso em: 16 abr. 2020.

DALTOÉ, Andréia da Silva; FERREIRA, Ceila Maria. Ideologia e filiações de sentido no Escola Sem Partido. Linguagem em (Dis)curso-LemD, v. 19, n. 1, 2019, p. 209-227.

DUGUIT, Leon. Fundamentos do Direito. São Paulo: Martin Claret, 2009.

ESCOLA SEM PARTIDO. Escola sem partido disponibiliza modelo de petição para garantir direito de líquido e certo de gravar aulas. Fev. 2020 Disponível em: https://escolasempartido.org/blog/escola-sem-partido-disponibiliza-modelo-de-peticaopara-garantir-direito-liquido-e-certo-de-gravar-aulas/. Acesso em: 26 mar. 2020.

FERRAZ JUNIOR, Tércio Sampaio. A erosão dos direitos subjetivos por força do desenvolvimento técnico (patentes, direito de autor). In: BAPTISTA, Luiz Olavo; FERRAZ JÚNIOR, Tércio Sampaio. Novos Caminhos do Direito no Século XXI: Direito Internacional, Filosofia Jurídica e Política, Dogmática Jurídica e Direitos Fundamentais. 2 ed. Curitiba: Juruá, 2013.

FREITAS, Maria Virgínia de. Jovens, escola democrática e proposta do "Escola Sem Partido". In: SOUZA, Ana Lúcia Silva et al (org.). A ideologia do movimento Escola Sem Partido: 20 autores desmontam o discurso. São Paulo: Ação Educativa, 2016, p. 101-108.

GADOTTI, Moacir. A Escola Cidadã frente à "Escola Sem Partido". In: SOUZA, Ana Lúcia Silva et al (org.). A ideologia do movimento Escola Sem Partido: 20 autores desmontam o discurso. São Paulo: Ação Educativa, 2016, p. 149-160. 
GAGLIANO, Pablo Stolze. PAMPLONA FILHO, Rodolfo. Novo curso de direito civil: responsabilidade civil. 2. ed. Saraiva: São Paulo, 2004. v. 3

GAZETA DO POVO. Gazeta do Povo tira do ar "Monitor da Doutrinação". Entenda por quê. Gazeta do Povo, 10 dez. 2017. Disponível em: https://www.gazetadopovo.com.br/educacao/gazeta-do-povo-tira-do-ar-monitor-dadoutrinacao-entenda-por-que-3lf43x0adm4bz2nc0p95/gqvo/. Acesso em: 26 mar. 2020.

GONÇALVES, Carlos Roberto. Direito civil brasileiro: Direito das coisas. 12. ed. Saraiva: São Paulo, 2017. v. 5.

GUGLIELMO, Brina. O que os pais podem fazer diante de casos de doutrinação ideológica?. Gazeta do Povo, 6 nov. 2017. Disponível em: https://www.gazetadopovo.com.br/educacao/oque-os-pais-podem-fazer-diante-de-casos-de-doutrinacao-ideologica-

9ket0n3op8kjeecb3sa7g1g82/. Acesso em: 26. mar. 2020.

LIMA, lana Gomes de; HYPOLITO, Álvaro Moreira. A expansão do neoconservadorismo na educação brasileira. Educação e Pesquisa, v. 45, 2019, p. 1-15.

MANHAS, Cleomar. Nada mais ideológico que "Escola Sem Partido" In: SOUZA, Ana Lúcia Silva et al (org.). A ideologia do movimento Escola Sem Partido: 20 autores desmontam o discurso. São Paulo: Ação Educativa, 2016, p. 15-22

MORAES, Vinícius de. O operário em construção. Rio de Janeiro, 1959. Disponível em: http://www.viniciusdemoraes.com.br/pt-br/poesia/poesias-avulsas/o-operario-emconstrucao. Acesso em: 26 mar. 2020.

OLIVEIRA, Ana Cláudia Rodrigues de; STORTO, Letícia Jovelina; LANZA, Fabio. A educação básica brasileira em disputa: doutrinação versus neutralidade. Rev. Katálysis, v. 22,n. 3, 2019, p. 468-478.

PANZOLINI, Carolina; DEMARTINI, Silvana. Manual de direitos autorais. Brasília: Tribunal de Contas da União, Secretaria-Geral de Administração, 2017.

PENNA, Fernando. O ódio aos professores. In: SOUZA, Ana Lúcia Silva et al (org.). A ideologia do movimento Escola Sem Partido: 20 autores desmontam o discurso. São Paulo: Ação Educativa, 2016, p. 93-100

RATIER, Rodrigo. 14 perguntas e respostas sobre o "Escola Sem Partido". In: SOUZA, Ana Lúcia Silva et al (org.). A ideologia do movimento Escola Sem Partido: 20 autores desmontam o discurso. São Paulo: Ação Educativa, 2016. p. 29-42.

RESEDÁ, Salomão. A função social do dano moral. Florianópolis: Conceito Editorial, 2009.

RIBEIRO, Vera Masagão. Apresentação. In: SOUZA, Ana Lúcia Silva et al (org.). A ideologia do movimento Escola Sem Partido: 20 autores desmontam o discurso. São Paulo: Ação Educativa, 2016, p. 5-8.

ROUSSEAU, Jean-Jacques. Do contrato Social. São Paulo: Folha de São Paulo, 2010.

SANTOS, Tiago Ribeiro; CERVI, Gicele Maria. D. Quixote, contra os moinhos: um ensaio sobre o Movimento Escola Sem Partido. Ensaio: Avaliação e Políticas Públicas em Educação, v. 27, n. 105,2019 , p. 712-731.

SCHMITT, Carl. O conceito do político. Belo Horizonte: Del Rey, 2008. 
SEVERO, Ricardo Gonçalves; GONÇALVES, Suzane da Rocha Vieira; ESTRADA, Rodrigo Duque. A Rede de Difusão do Movimento Escola Sem Partido no Facebook e Instagram: conservadorismo e reacionarismo na conjuntura brasileira. Educação \& Realidade, v. 44, n. 3, 2019, p. 1-28.

SILVEIRA, Newton. Propriedade intelectual: propriedade industrial, direito de autor, software, cultivares, nome empresarial, título de estabelecimento, abuso de patentes. 6 ed. Barueri: Manole, 2018.

SOUZA, Ana Lúcia Silva et al (org.). A ideologia do movimento Escola Sem Partido: 20 autores desmontam o discurso. São Paulo: Ação Educativa, 2016.

SUPREMO TRIBUNAL FEDERAL. Medida cautelar na ação direta de inconstitucionalidade 5.537 Alagoas. Relator: Ministro Luís Roberto Barroso. Brasília: 21 mar. 2017. Disponível em: https://portal.stf.jus.br/processos/downloadPeca.asp?id=311456113\&ext=.pdf. Acesso em: 26 mar. 2020.

VASCONCELOS, Joana Salém. A escola, o autoritarismo e a emancipação. In: SOUZA, Ana Lúcia Silva et al (org.). A ideologia do movimento Escola Sem Partido: 20 autores desmontam o discurso. São Paulo: Ação Educativa, 2016, p. 77-82.

XIMENES, Salomão. O que o direito à educação tem a dizer sobre "Escola Sem Partido"? In: SOUZA, Ana Lúcia Silva et al (org.). A ideologia do movimento Escola Sem Partido: 20 autores desmontam o discurso. São Paulo: Ação Educativa, 2016, p. 49-58. 